\title{
It's politics, stupid! A political analysis of the HIV/AIDS Trust Fund in Uganda
}

\author{
Authors: Charles Birungi ${ }^{1,2^{*}}$, Timothy Colbourn ${ }^{1}$ \\ ${ }^{1}$ Institute for Global Health, University College London, UK; ${ }^{2}$ UNAIDS, Zimbabwe. \\ *corresponding author email: charles.birungi.14@ucl.ac.uk
}

\begin{abstract}
The role of trust funds in the practice of and the policy discourse on the sustainable financing for health and HIV is growing. However, there is a paucity of political analyses on implementing trust fund arrangements. Drawing on a novel meta-framework - connecting multiple streams and advocacy coalition frameworks to policy cycle models of analysis - to politically analyse HIV financing policy design, adoption and implementation as well as insights from public finance literature, this article critically analyses the politics of the HIV/AIDS Trust Fund (ATF) in Uganda. We find that politics was the most fundamental driver for the establishment of the ATF. Whereas HIV financing is inherently both technical and political, enacting the ATF was largely a geopolitical positioning policy instrument that entailed navigating political economy challenges in managing multiple stakeholder groups' politics. With the mandated tax revenues earmarked to capitalize the ATF covering only 0.5 percent of the annual resource needs, we find a very insignificant potential to contribute to financial sustainability of the national HIV response per se. As good ideas and evidence alone often do not necessarily produce desired results, we conclude that systematic and continuous political analysis can bring meaningful insights to our understanding of political economy dimensions of the ATF as an innovative financing policy instrument, thereby helping drive technically sound health financing policy proposals into practice more effectively. For Uganda, while proponents have invested a considerable amount of hope in the ATF as a source of sustainable domestic funding for the HIV response, substantial work remains to be done to address a number of questions that continue to beguile the current ATF architecture. Regarding global health financing policy, the findings suggest the need to pay attention to the position, power and interests of stakeholders as a powerful lever in health financing policy reforms.
\end{abstract}

Key words: Africa, Uganda, trust fund, universal health coverage, health finance, fiscal policy 


\section{Introduction}

This article undertakes a political analysis of the AIDS Trust Fund (ATF) as a public policy instrument for financing the HIV response in Uganda. Health and HIV financing is inherently political. Economics and politics are co-determined, especially with regard to fiscal policy and politics, so this article analyses HIV financing in Uganda from a political economy perspective. It offers insights into "the politics of health policy change, the interests and actors driving the processes through which policies are developed and implemented" (Gilson, 2012, p. 22). Understanding the political dimensions of HIV financing is critical for devising effective strategies to improve the sustainability of the national HIV response. However, there is a paucity of such evidence to inform current discourse on trust funds in domestic HIV and health financing.

Thirty-five years since the first HIV case was identified and documented, Uganda - one of the countries hardest hit by HIV in the world - has changed the trajectory of the AIDS epidemic. New HIV infections and AIDS-related deaths are at an all-time low, declining since 2010 by $51 \%$ and $45 \%$, respectively (UNAIDS, 2018). At the end of $2017,90 \%$ of all people living with HIV (PLHIV) who knew their status were on life-saving antiretroviral therapy (ART; UNAIDS, 2018). ART is indubitably one of the great successes of global health, reducing AIDS-related morbidity and mortality and slowing onward HIV transmission. Decades-long impacts of HIV/AIDS on mortality, as mirrored in declines in life expectancy, have been reversed. However, as global health history shows, a global epidemic has never been ended without a functional cure or vaccine. Wilson and Görgens (2016) argues that HIV is no exception. Relatedly, it is highly unlikely that Uganda will achieve the 2020 UNAIDS fast-track targets to achieve an epidemic transition. In fact, as funding declines and political commitment wanes, there is no end to AIDS in sight, as Wilson and Whiteside (2016) argue. This state of affairs has long-term developmental and financial implications as new infections remain stubbornly high and treatment costs rise inexorably.

In Uganda, HIV spending accounts for $37.5 \%$ of total health expenditure. As Figure 1 shows, on the one hand, domestic public financing for HIV has remained dismal, averaging $9 \%$ over the last 17 years. On the other hand, external funding has been and remains the main source of funding for the national HIV response. However, it is important to note that external funding is currently at a crossroad and faces an uncertain outlook (Booth \& Whiteside, 2016; Haacker, 2016; Whiteside, 2019; Whiteside, 2016; Johnston, Deane, \& Rizzo, 2018). Previously unprecedented global support for financing global interventions in the 1990 s to late 2000 s is waning, primarily due to five main factors.

First, the 2007/8 global economic crisis exerted fiscal pressure on high-income Organisation for Economic Cooperation and Development (OECD) countries' aid budgets (Dieleman et al., 2018). Second, changes in the global health financing landscape are heightening uncertainties around future aid flows. Due to relatively high economic growth in a number of countries with a high HIV burden, there is more focus on domestic resource mobilisation for HIV and health as some countries graduate from low- to middle-income country status, a transition that changes their eligibility for accessing some multilateral and bilateral development assistance. Third, some analysts (Moszynski, 2010; Grépin, 2012) have attributed this trend to "donor fatigue", i.e. donors capping, reducing or withdrawing spending commitments to HIV responses because they have been involved in the HIV response for long and/or AIDS is over. As the historiography of HIV financing in Uganda shows (Birungi, 2019), most aid is still largely charity, as the words "donor" and "recipient" imply. Thus, under this changing funding paradigm, long-term commitments to future aid are difficult for many donor governments who face legislative constraints and also cannot commit their successors. Donors also wish to retain some flexibility to react 
to current events and are reluctant to tie up significant portions of their budgets in long-term commitments. Finally, ending AIDS is a global public good and thus calls for global responsibility. However, growing populist national politics is anathema to international cooperation and mutual solidarity, the very values needed to end AIDS as a global public health threat (Gostin \& O Cathaoir, 2018). In light of the above, Uganda should expect foreign aid to fall, particularly as it transitions from being categorised as a low-income to a middle-income country. It is imperative to make an honest effort to reduce Uganda's dependence on outside aid.

Figure 1: HIV spending in Uganda, 2000 - 2016 (in 2018 purchasing power parity-adjusted US dollars)

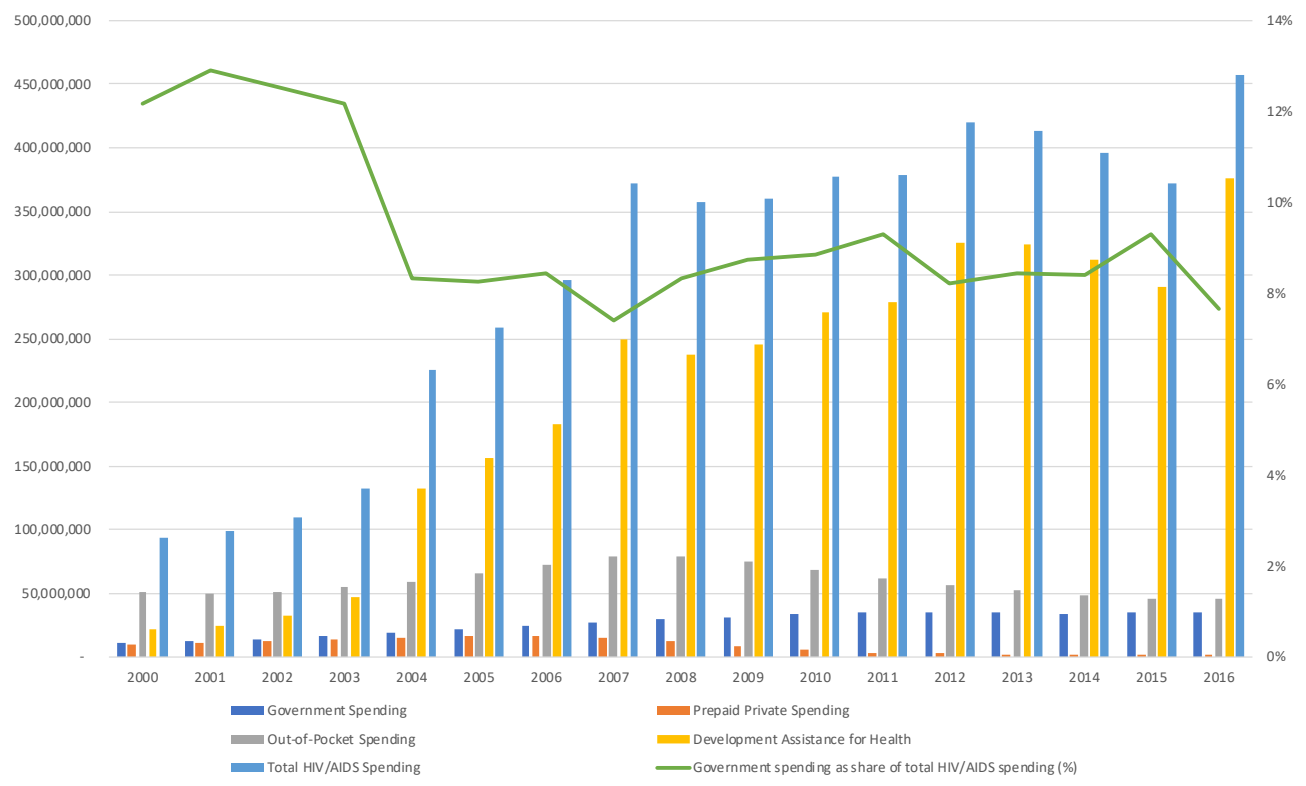

Source: Authors' analysis from IHME (2019).

From a political economy perspective, the state of HIV/AIDS financing presents a policy dilemma. National programs are a long-term financial commitment (Over, 2008; Haacker, 2016). On the one hand - with 1.3 million PLHIV in Uganda in need of life-long ART - there is a rise in overall costs of HIV/AIDS programmes due to a commitment to achieving universal access, and growing need for services. On the other hand, there are limited domestic public funds available while external funding on which the national HIV response has largely depended - is declining. Such dynamics pose a challenge to the sustainability of the national HIV response. It is in this context that the national AIDS Trust Fund (ATF) was conceived as an innovation for domestic resource mobilisation and to get associated legislation passed.

Globally, proposals for establishing health trust funds have featured in recent and current policy dialogues about domestic HIV/AIDS financing. This has, in part, been motivated by shifts in the health financing landscape. These changes include the move to achieve universal health coverage and the sustainable development goals; the need to increase pooled, prepaid financing and move away from 
out-of-pocket expenditures; and reduce dependence on external development assistance as countries cross income- related eligibility thresholds or as donors gradually withdraw from specific programmes such as HIV-related funding). In the literature on public financing of health and HIV programs, trust funds have been part of the policy discourse on the sustainable financing of the HIV response for many years, but mainly on the global level.

The Global Fund against HIV/AIDS, TB and Malaria (hereafter the Global Fund) - the most significant multilateral funding agency - is a trust fund. As used in this article, trust funds refer to extrabudgetary funds for dedicated purposes (Haacker, 2016; Kumar \& Bhawalkar, 2016; Birungi, 2019). Trust funds have been discussed in recent years in the context of increased domestic responsibility and a decline in donor commitments. In practice, however, trust funds are seen as policy instruments for isolating the HIV response from the annual domestic budget process by enhancing autonomy in investment decisions, introducing flexibilities into public finance (such as enabling rolling money over one year to the next) and, establishing an inviting environment for new forms of finance. However, experience with HIV/ AIDS trust funds is thin. Zimbabwe's AIDS levy, which has been operational since 2000 , provides one example of a fully developed trust fund supporting the domestic HIV response. Uganda and Tanzania have also recently established ATFs. In Kenya, despite strong advocacy and cabinet approval in 2012 to establish a trust fund for HIV and priority communicable diseases, it is yet to be translated into policy and receive parliamentary approval. While there are other examples of health and disease-specific trust funds, such as the Hong Kong AIDS Trust Fund and Bhutan Health Trust Fund, among others, these are conceived as endowments, that is, funding key health services from investment income rather than from government allocations or other contributions. It appears that recent trust fund proposals conflate investment funds with extra budgetary funds. Generally, there is a paucity of literature on trust funds as a health financing mechanism. It is this gap that our article aims to fill by exploring how the ATF got onto the political agenda in Uganda.

The body of this article is structured in four sections. First, we present the methods used in our study. Second, results are presented. Here, we consider the critical influences on HIV financing policy processes in Uganda - power in policy change, the national context, and global health actors and national policy-making. In particular, we present an analysis of how the ATF got onto the political agenda. This offers particularly valuable insights for countries seeking to reformulate their own health financing policies. The third section discusses the results in light of the original rationale advanced for the ATF, as well as key design features as approved by Parliament. It includes pointers to the costbenefit analysis of this innovative domestic resource mobilisation instrument. To place the ATF revenue raising potential in context, we compare it to national HIV response resource needs.

\section{Analytical framework}

This article employs a process tracing methodology, guided by the Five-Stream Framework of the Policy Process (Howlett, McConnell, \& Perl, 2016). In policy studies, various analytical frameworks have been developed since the 1980s. These approaches to understanding policy processes include, amongst others, the stages of policy cycles, multiple streams, and the Advocacy Coalition Framework. While they all have analytical value, used alone they have attracted substantive criticism. For example, given its overwhelming focus on agenda-setting, Kingdon's model (Kingdon, 1984) cannot simply be transplanted directly to explain non-agenda-setting dynamics. Additionally, the Advocacy Coalition Framework - at least in the form developed by Sabatier and others - is unable to offer satisfactory insights into 
important aspects of policy-making such as mechanics of ratification or rejection of policy options, or the administrative politics of programme implementation. To this end, as both John (1998) and Cairney (2013) have argued, one way out of the conundrum of multiple, competing frameworks attempting to explain the same set of facts, is to stop viewing them as mutually exclusive or competitive constructs. As Figure 2 shows, to advance thinking about policy-making, the hybrid meta-framework used in this article addresses the above criticisms and draws on both John and Cairney's advice.

\section{Figure 2: Five-Stream Framework of the Policy Process}

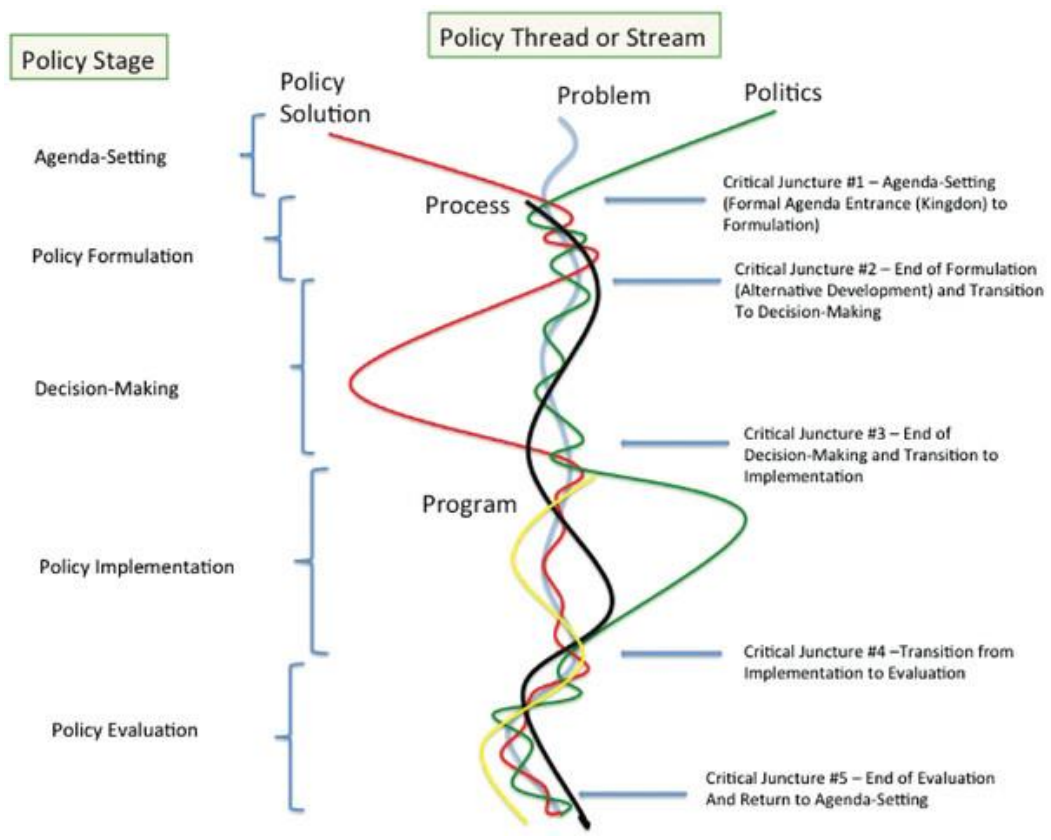

Source: Howlett, McConnell and Perl, 2016

This framework represents a methodological advance for assessing policy developments because it recognises and incorporates the intertwined nature of policy-making and the influence of political agendas on the process. Additionally, it emphasises how the above are integrated from the start (the step to create a policy) and occur during that part of the process and even in the making of policy, and during implementation. In light of this, each confluence point brings something new - new actors, new tactics, new ideas, new resources - in the flow of policy-making events. Where each stream intersects, the merger point represents a "window" in Kingdon's sense (Kingdon, 1984) and yields a different configuration of policy inputs that generate a distinct policy pattern through each particular juncture, much as the "rounds" style of policy-making theories have suggested (Howlett, McConnell \& Perl, 2016). At an applied level, at each policy stream, we critically asked the following four inter-related questions: (1) Who participates in the issue? (2) What do the participants want and why? (3) How does the decision process work? (4) What determines each player's relative power in the decision-making process? 
Adopting a policy-oriented approach, we present the results in terms of actors involved (and their relative power); how, where and what interests emerged; and the role of ideas, issues, interests, ideology, institutions and information. In health economics and policy literature, the policy-oriented approach primarily seeks to understand how the machinery of the state and political actors interact to produce public action (John, 1998; Poku \& Whiteside, 2006). Here, the links and interplay between sources of disruption are more important than individual factors taken in isolation. To this end, the context of Uganda circa 2010 (when the policy of establishing an ATF policy process began in earnest) is important to why it was approved. As the chronology $f$ HIV financing policy presented in Appendix I shows, in the context of huge budget constraints and the big burden of preventable and infectious diseases, it is interesting to study how HIV financing (a long-term fiscal sustainability challenge whose full magnitude and evolution was not fully known) got onto political agenda. Below, we present the context, players, processes and outcome.

As shown earlier, at the global level, the health financing landscape was undergoing rapid changes. Importantly, the period leading to the enactment of the ATF coincided with one of declining external funding and concomitant increasing demand from donors - in the spirit of counterpart funding required under "shared responsibility" principles - to mobilise domestic funds for the HIV response. In this global context, the limited explicit understanding of what trust funds mean notwithstanding, the Ugandan proposal of the ATF, as contained in the Uganda AIDS Commission policy note (Uganda AIDS Commission, 2017), was meant to be an entity within the public sector dedicated to funding AIDSrelated spending. The objectives were broadly defined in terms of enhancing self-sufficiency as well as leveraging donor and private sector contributions.

In Uganda, the financing of HIV services has evolved progressively. Four distinctive but overlapping phases are discernible. First, from the start of the epidemic in the early 1980s, individuals and households paid out-of-pocket for essential care. Second, out-of-pocket payments were complemented by government and faith- and community- based organisations financing home-based care, orphan support, and treatment of opportunistic infections in the late 1980s. This period was followed by some minimal external support from the Global Programme on AIDS, among other donors. During the third phase starting in the early 2000s, substantial HIV funding emerged with the advent of global health initiatives such as the 2002 Global Fund and the US President's Emergency Plan for AIDS Relief (PEPFAR) in 2003. Finally, the current phase since the global economic crisis of 2007/8, is marked by the challenge on how to sustain HIV programmes given declines in external funding and changing donor aid agendas. In addition, given the risk of losing control of the disease (in terms of reducing HIV incidence substantively), this challenge is exacerbated not only by the costs of treating already-large numbers of PLHIV but also sizeable numbers of newly infected people in the years ahead.

Noteworthy, during this latest phase - owing to weak institutions and governance challenges HIV financing has been exposed to fiduciary risks. First was the mismanagement of Global Fund resources in 2006 and the ensuing (temporary) suspension of grants. Additionally, the period from 2008-2013 witnessed forensic audits that unearthed financial misappropriation at the Partnership Fund as well as the Civil Society Fund (see Appendix A). These, in turn, exerted pressure on the Ugandan AIDS Commission. Key actors such as Healthcare Development Partners Group and the AIDS Development Partners Group - funding the broader health sector and the HIV response, respectively - capitalised on these fractures to call for stronger fiduciary measures. These micro-politics that were part of the process 
over several years, among other factors, have heightened the fiduciary risks in Uganda's national HIV programmes. This is the context in which the AIDS Trust Fund policy was enacted.

Power was an important driver of how the ATF got onto any agenda. Uganda is a bureaucratic society; as a result, power vested in an individual - the director general of the Uganda AIDS Commission (UAC) - went a long way in getting (sustainable) HIV financing on the political agenda. As Sadan (1997) previously argued, power refers to the probability that an actor within a social relationship would be in a position to carry out his will despite resistance to it. Conversely, resistance to this sort of power may provide a strategic opportunity. The period of advancing the ATF coincides with a period when donors suspended financial support to the UAC. Thus, resistance by international donors, which could have been interpreted as questioning of the director general's authority and threatening to bring his legacy at the UAC into disrepute, provided an opportunity for him to champion the establishment of the ATF. This is very similar to how a tough tobacco control bill was passed in Thailand following the country being forced by the General Agreement on Tariffs and Trade to open up the cigarette market. It was a matter of "national pride and 'face'" (Chantornvong \& McCargo, 2001). Another champion worth mentioning is the chair of the UAC, a renowned researcher and academic who previously worked on innovative financing at the Global Fund. His personal close relationship with the President of Uganda enabled navigating "leadership politics" (Campos \& Reich, 2019 p. 231).

Positively, development partners influenced ATF policy. Here, as in most low-income countries heavily dependent on external funding (Kapiriri \& Norheim 2004; Colenbrander, Birungi, \& Mbonye, 2015), external development partners played a part in enabling national policy processes, such as providing technical and financial support to develop the concept note on the ATF. However, we observed that such influence and the power it reflects is often hidden from view through various practices of effacement or concealment that downplay foreign agency and attribute it to national or local actors. Partners preferred, and continue to prefer, to be described as just one of many actors who contributed to policy development. Particularly, they sought to take a back seat and keep a low profile, preferring the government to clearly remain in the driver's seat, even going so far as to request their contributions remain anonymous in the policy note that first proposed the ATF.

To better understand the key political economy dimensions navigated in enacting the ATF in Uganda, below we analyse some key stakeholders and whether they were supportive or not. First, the United Nations (especially UNFPA, UNDP and UNAIDS) strongly supported the establishment of the ATF. As part of the UN Joint Programme of Support on AIDS, they provided technical support for developing the policy note that informed the ATF. Additionally, the development partners (including UN agencies), self-organising under the AIDS Development Partners Group, supported this nascent proposal. This unequivocal support can be explained by four main factors.

First, a number of these development partners had positive experiences with the modus operandi of trust funds (out of the HIV and health sector). In fact, during the 2012 AIDS Partnership Forum, development partners had participated in a round-table discussion and advocated (strongly) for the establishment of an ATF (e.g. Birungi, 2012). Second, the experience of the Zimbabwe AIDS levy (which was a relatively well-known as an early success story of moves towards sustainable innovative domestic financing of health and HIV services) was gaining recognition in policy circles. It was envisaged that, if adequately capitalised and professionally managed, the ATF could fill the financing gap in case donor funding ceased. Finally, cognisant of the three functions of health financing (i.e. raising, pool and strategic purchasing; WHO, 2010), and given the fiduciary assurance issues unearthed by the forensic audit referred to earlier (see Appendix A for details), donors hoped the designed features of the ATF 
would, besides innovatively raising domestic resources, encompass pooling and strategic purchasing functions. Using the ATF to strategically purchase antiretroviral drugs was seen as a possible option. With prudent governance and adroit management, it was envisaged that this would strategically facilitate this new financing vehicle (i.e. the ATF)

On the other hand, owing to the well-known shortcomings of trust funds from a public finance perspective, such as constraining government's fiscal operations, by reducing the capabilities of policy makers to respond to changing circumstances and shifting priorities (Potter \& Diamond, 1999), one would naturally have expected opposition from the custodians of both monetary and fiscal policy, namely the Treasury and World Bank and the International Monetary Fund (IMF).

In contrast, the World Bank strongly supported the establishment of the ATF owing to their deep appreciation of the fiscal dimensions of HIV. Partly drawing from their own commissioned analytical work (Lule \& Haacker, 2011), they called for sustainable financing of HIV-induced fiscal liabilities and the ATF was seen as one step in this direction. The Ministry of Finance, Planned and Economic Development (MoFPED) - thanks in part to personal relations between then Director General of the UAC and then Secretary to the Treasury (who is the permanent secretary and thus accounting officer of the MoFPED) - favourably assessed the pros and cons of the policy proposal and provided a clean certificate of financial implications which signalled to the Bill drafters (and eventually Parliament) the MoFPED's in-principle endorsement. Also, key incumbents of the executive and legislative arms of government were in support of the ATF, in principle, because the policy resonated with the interests and ideas of the ruling coalition. The ATF was a means to advance aspirations of self-reliance and resource mobilisation for development.

Additional support came from civil society. Organisations such as the Uganda Network of AIDS Service Organisations, Centre for Health Human Rights and Development, Alliance of Women Advocating for Change, International Community of Women Living with HIV/AIDS, AIDS Healthcare Foundation, and Health Global Access Project, among others, strongly argued that this policy development represented an important opportunity to generate additional revenue to augment Uganda's effort towards "ending AIDS". However, on the ground, those involved in HIV financing policy negotiation, formation, and implementation, in the spirit of activism, raised five critical areas of concern:

1. The revenue raised by the ATF should be sufficient to contribute meaningfully to the goal of ending the AIDS epidemic in Uganda;

2. The ATF board should be an independent body with actual or perceived conflict of interest aggressively managed;

3. Civil society and other stakeholders should work to ensure transparency, accountability and freedom from corruption;

4. The ATF should be a multi-stakeholder body; and

5. The revenues raised should be strategically invested in programme areas with direct impact on preventing new HIV infections and averting AIDS deaths, and verifiable.

Unexpectedly, the main opposition to the proposal was from the Ministry of Health (MoH) although, most times at least, this was expressed diplomatically behind the scenes. The planners and policy makers in the $\mathrm{MoH}$ were heavily influenced by priority setting using burden of disease data and thus contended that HIV/AIDS was no longer a top priority because mortality and morbidity had greatly declined due to ART. This view was contrary to the required long-term perspective that frames HIV as a 
long-term fiscal liability for which the imperative to find sustainable financing solutions was key. The $\mathrm{MoH}$ actors argued that sustainable financing should be for the broad health sector and not a single disease. It is important to note, however, that behind these technical arguments there was a longstanding rivalry between the $\mathrm{MoH}$ and the UAC due partly to overlapping mandates - and the attendant competition for funding from treasury and donors for HIV interventions.

There are two issues worth mentioning in an attempt to explain the opposition from the MoH which would otherwise have been a natural supporter. First, the ministry had proposed a national health insurance scheme (NHIS) and a corresponding fund whose design was facing challenges, among these a 2001 presidential decree abolishing user fees at point-of-use at public health facilities. Elements within civil society, government and the general citizenry questioned what risk NHIS would cover given the free health care policy enacted. Technically, there is not necessarily a contradiction between free health services and an NHIS; however, the framing of and reaction to the NHIS displayed the internal politics of ATF supporters seeking to discredit the NHIS. Thus, at the time the ATF was proposed, it was unclear how and if the two funds (i.e. the ATF and the NIH fund that was proposed to pool and strategically purchase health services using the NHIS premiums) could efficiently and effectively synergise with each other. In the face of this lack of clarity, a number of actors within the MoH opted to oppose the ATF until clarity was provided. It is important to note that whereas the NHIS was contradicted by the presidential decree, MoH continued advocating for the NHIS long afterwards and, by the late 2000s, was advocating for the NHIS as an equitable mechanism to help finance costs incurred for free health services.

Second and related to the above is the role of the Health Development Partners Group (HDPG) whose membership was often different from the AIDS Development Partners Group (ADPG) with minor overlaps between these coalitions. The HDPG supported the position of the $\mathrm{MoH}$ for the above reasons but also contended that the ATF would further verticalise the HIV response, yet the move was to integrate the same into broader health systems (and run a resilient and sustainable horizontal health system).

Positing that political analysis is an essential part of policy analysis, we also highlight the critical importance of analysis and engaging with power vested in institutions, which is not absolute as it depends on the rules of the game in those key institutions. Additionally, sources of power in institutions include knowledge, resources, reputation, control of key procedural check-points, and self-awareness. To this end, as the Parliamentary Committee on HIV and AIDS is silent about the approval of the ATF operational guidelines, this could safely be interpreted to signal the dynamics between power and politics between the legislature and MoFPED in resourcing the ATF, and partly explain why operationalisation of the ATF has taken longer since the departure of the DG at UAC.

Finally, we show that major policy change is preceded by dramatic events. The ATF as an HIV financing policy instrument did not get onto the agenda out of the blue; there had been action behind the scenes, some very quietly. As a key lesson to managing the attendant politics of health financing for universal health coverage, this article highlights the key political economy challenges that need to be analysed and addressed for sustainable HIV and health financing. 


\section{Discussion}

The financing of HIV services in Uganda has a unique political history; the politics of HIV financing is inextricably linked to the politics of AIDS in Uganda (Tumushabe, 2006). Using a theoretical framework called geopolitical positioning (Gómez, 2017), we contend that Uganda - as a nation - responded to international pressures and policy criticisms. HIV financing having been criticised for "displacing" other funding for health and development (Shiffman, 2008), the country strategically utilised the ATF as a domestic policy innovation to ultimately (re)engage in global health diplomacy in order to bolster its international reputation. It is worth mentioning that this was also partly a response to offers of financial and technical assistance from, for example, the Global Fund and was thus projected to raise revenues to meet the co-financing policy requirement.

Efforts to push for the ATF were domestically driven primarily with calls for additional revenue; unfortunately, there was little focus on how the money should be spent. Buoyed by enthusiasm about raising private and public capital, we argue that the ATF conflated budgetary vehicles with investment funds. This is an important policy consideration that remains unanswered. Conflating these two models is problematic as it signifies a lack of clarity on whether the ATF as an investment fund (such as in the case of the Bhutan Health Trust Fund (BHTF) seeks financial independence from government altogether or, as a budgetary vehicle seeks temporary breaks from government interference on spending while relying on government revenues. Second, as shown earlier, the ATF seeks earmarked sources of revenues. From a public finance perspective, while the case for hypothecation is well argued with all pros and cons systematically analysed elsewhere (Cashin, Sparkes, \& Bloom, 2017), for the Ugandan ATF a key question remains: can it spend money more effectively than other government bodies? Finally, calls for integrating HIV services with other health services as practicable have been made. We argue that the ATF runs a risk of prioritising spending with direct HIV outcomes and less for structural interventions with long-term benefits for health. Relatedly, as AIDS spending is often delivered through structures parallel to the health system, it is highly likely that the ATF risks compounding verticalisation. These are important considerations for rethinking the current architecture of the ATF.

In relation to the role of individuals, preferences within individuals are relatively fixed and slow to change. In navigating the politics of evidence-informed policymaking, as one of the strategies of influential policy actors, it is acknowledged that preferences get activated by how individuals interpret the context (True, Jones, \& Baumgartner, 2007; Parkhurst, 2017). One thing that was done in Uganda was to extrapolate and interpolate global evidence on the looming global HIV financing crisis due to end of the era of solid global aids funding support for HIV responses (referred to as the end of the "golden age" elsewhere (IHME, 2010). This mobilised the support of the general public and the political leadership, particularly the executive, legislature and civil society. Specifically, during the public hearings on the proposal in Parliament, the ensuing big turnout and related advocacy efforts served as subtle indications to policy makers that there was support from below.

Relatedly, the individual policy entrepreneur is critical to the policy process. The policy entrepreneur recognises a window of opportunity when it opens and is quick to act. They are described as "not mere advocates of a particular solution; they are power brokers and manipulators [that word 
again]...they are persistent, skilled at coupling, they are able to attach problems to their solutions and find politicians [or health policy makers] receptive to their ideas" (Zahariadis, 2007, p. 74). In Uganda, having a politically astute UAC DG, who took this on and worked persistently to get the ATF on the agenda, taking advantage of all opportunities that arose, was critical to getting ATF on the agenda. Key attributes of the policy entrepreneur are key to this. Three of these stand out. First, having actively participated in The aids2031 AIDS Consortium's costs and financing Technical Working Group (TWG), he was well aware of the looming financing crisis for the global response to the AIDS epidemic and the need to act swiftly. Second, within the ruling coalition, Parliament and the Executive, he had earned the trust of the actors therein. In the process of championing the ATF, he capitalised on this goodwill and exploited it to advance the proposal. Third, having been at the helm of coordinating the national HIV response for more than two decades, he had a good appreciation of potential potholes for the proposal as well as requisite framing language to connect with the various actors.

Beyond the role of the policy entrepreneur who takes advantage of a policy window opportunity, attention ought to be paid to collective action. Here, mass mobilisation, sensitisation and awareness sessions during the Partnership Forum and through the various self-coordinating entities' engagement platforms, HIV-related national and sub-national events (such as the Candlelight Memorial and World AIDS Day) and advocacy from and within the loose umbrella entity "Uganda HIV Advocates", played a significant role in getting ATF policy proposal approved. Specifically, here, the various calls for the ATF during speeches as well as written memoranda such as those on draft Statutory Instruments before Parliament helped galvanise support to get it approved.

In policy studies, institution is defined as "the context within which individuals act" (Schlager, 2007), including "national mood" (Zahariadis, 2007, p. 73). The euphoria in Uganda after years of sustained peace, with development indicators improving, the fight against AIDS as a global "success story", the sense of being able to hold heads high again, that mood was important. The mantra of "Ugandan solutions to Ugandan challenges" has been growing in importance. The ATF policy proposal, in effect, was deemed to offer domestic financing solutions to HIV.

It thus follows that the importance of the policy entrepreneur being strategically positioned in an institution cannot be over-emphasised. As additional micro-political aspects of the policy process show, the DG of UAC was institutionally located in the Office of the President (and directly appointed by the President), and so indirectly, the power inherent in the institution (the Presidency) was reflected in the policy entrepreneur. The Presidency, having led the early efforts in the fight against HIV/AIDS, still has the mandate to develop HIV financing policy (see Presidential Fast Track Initiative to End AIDS in Uganda, Government of Uganda, 2017, for example). Some observers, noting that the DG's son was groomsman during the wedding of the President's son, have contended that he was politically connected and powerful. Additionally, being related (by blood) to the Secretary to the Treasury who controlled a powerful tool, fiscal policy (that is currently under-utilised by the government and leaders to finance health) was key to assenting and granting a certificate of financial implications for the Bill in which the ATF proposal was embedded.

In designing policy and driving its adoption and implementation, we find that multiple stakeholders may use similar strategies or a mix of overlapping strategies to promote, block or slow down policy design, adoption and implementation. The policy reform entailed navigating six dimensions of political economy. These are in line with those proposed by Campos and Reich (2019). As shown in Figure 3, in no particular order, the policy process entailed navigating competing interest groups' politics. For example, civil society activists sought to minimise losses, whilst maximising gains from 
reform. The contentions with Ministry of Health ably illustrate bureaucracy politics. In particular, this entailed contestation of reform to protect or expand authority, interests, budget, personnel, or influence. Whereas overall tax administration and collection, as well as revenue allocation typically lie with finance authorities, managing budget politics influenced reform as negotiations between UAC and MoFPED regarding budget allocation and expenditure mechanisms showed. In terms of leadership politics, here electoral cycles, party politics, and context shaped opportunities for reform. Particularly, to the political leadership, this reform was positively viewed as conferring political legitimacy through the delivery of socioeconomic progress. In terms of beneficiary politics, the analysis shows that ideas and ideologies matter. In the case of the ATF in Uganda, this entailed navigating the reform complexities through alignment with national values and identities, including public opinion. Finally, it is generally accepted that external actors can be very influential. Thus, in terms of external actor politics, external donors did lend support to this policy. In a nutshell, this study of the politics of HIV financing demonstrates the complex politics involved.

Figure 3: Key political economy dimensions navigated in enacting the ATF in Uganda

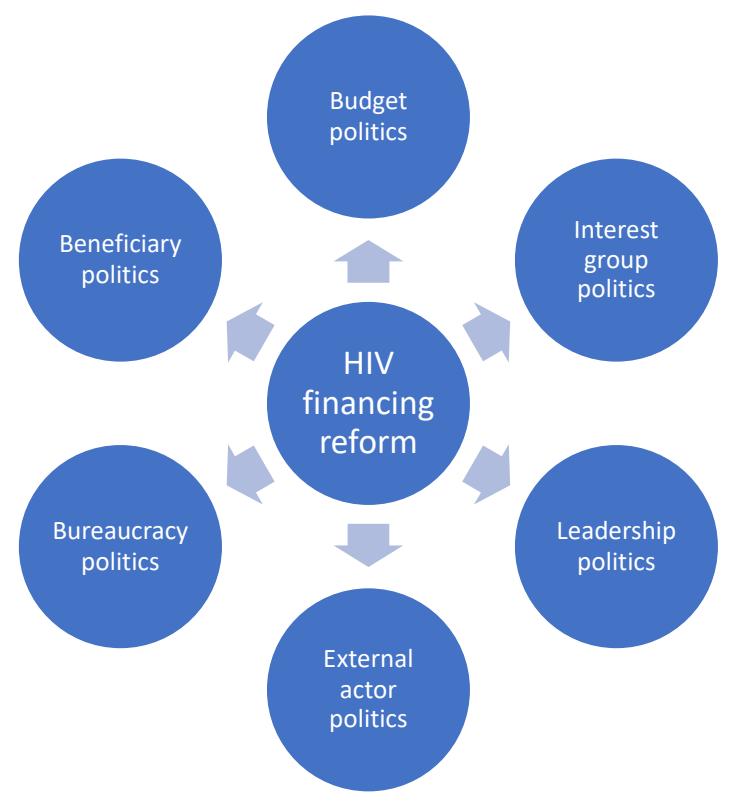

Source: Authors' adaptation from Reich and Campos (2019).

Methodologically, the framework used in this article is well suited to analyse the micro-politics of HIV financing reform. Current policy theory has not moved very far beyond the original ideas advanced in the writings of the 1980s and 1990s. Applying this novel framework, as we do in this article, is one way out of the conundrum of multiple, competing frameworks attempting to explain the same set of facts. We posit that the research possibilities involved in working with this new framework are enormous, once we begin to see the value in adapting and combining the core insights of stages, streams, and coalition approaches, rather than seeing them as mutually exclusive. Specifically, it allows us to meld together analytical approaches that focus on different stages of policy processes, the 
interplay of multiple forces that shape these processes, and the competition between different sets of actors (and beliefs) as they vie for influence.

In conclusion, globally, proposals for establishing trust funds have played a role in the recent and current policy dialogue on domestic HIV/AIDS financing. This has, in part, been motivated by the need to increase domestic financing for HIV and health, in response to shifts taking place in the global health financing landscape. Among others, these changes include the move to achieve universal health coverage and the sustainable development goals; the need to increase pooled, prepaid financing and move away from out-of-pocket expenditures; and the transition away from, or reduction in, development assistance, as countries cross income-related eligibility thresholds or as donors gradually withdraw from specific programs (e.g. in HIV/AIDS-related funding). However, to the best of our knowledge, there is a paucity of literature on the politics and economics of trust funds as health financing mechanisms. This article attempts to fill the gap by contributing to the academic literature on the politics and role of trust funds for fiscally and politically sustainable financing of HIV responses. While not detracting from the value of this analysis, in interpreting our results, it is important to bear in mind one limitation. At the time of writing this article, the ATF - despite being legally established in 2014 - was not yet fully operational as to enable a full benefit-cost analysis of this policy instrument. What is known, however, is that its revenue raising potential from some tax revenues directly assigned by law to the ATF account for about US\$ 2 million (translated into around $0.5 \%$ of annual total HIV/AIDSrelated spending) (Birungi, 2019).

\section{Conclusions}

In this article, we have analysed the political economy of the ATF as a health financing policy instrument. While the ATF was a technically sound health financing policy, its design, adoption and implementation were and continue to be influenced by political economy factors. Also, while technical arguments were used, the article finds that these are insufficient in explaining Government of Uganda's decision to pursue the enactment of the ATF as a domestic policy tool for sustainable financing of the national HIV response. Instead, the findings suggest that politics was the factor that plausibly explains this health financing policy reform to get the ATF policy on the political agenda. As the revenue raising potential of ATF from the mandated sources is very insignificant, covering a paltry 0.5 per cent of annual resource needs (before netting out the ATF's administrative costs), the findings illustrate little evidence on likely positive contributions of the ATF to ensure the financial sustainability of the national HIV response per se. As a key lesson to managing the attendant politics of health financing for universal health coverage, to stimulate thinking and working politically, this article highlights the key political economy challenges that need to be analysed and addressed to design, adopt and implement sustainable HIV and health financing policy reforms that could move Uganda towards universal health coverage.

Disclaimer: This article does not represent the official views of affiliated organisations but rather the personal views of the authors. 


\section{References}

Basaza, R. K., O'Connell, T. S., Chapcakova, I. (2013). Players and processes behind the national health insurance scheme: a case study of Uganda. BMC Health Services Research, 13, 357. https:// doi.org/10.1186/1472-6963-13-357

Birungi, C. (2019). Reconciling the irreconcilable? An application of economics to long-term fiscal sustainability of the HIV and AIDS response in Uganda. (PhD thesis). University College London, London, U.K.

Birungi, C. (2012). Innovative financing: What can Uganda learn from international experience? Presentation at the AIDS Partnership Forum, Kampala, 16-19 October.

Booth, P., \& Whiteside, A. (2016). Expanding the fiscal space for health in Africa. Geneva, Switzerland: The Global Fund.

Cairney, P. (2015). The Politics of Evidence-Based Policy Making. London: Palgrave Macmillan.

Cashin, C., Sparkes, S., \& Bloom, D. (2017). Earmarking for Health: From Theory to Practice. Geneva: World Health Organization. https:// www.who.int/health_financing/documents/earmarking-forhealth/en/

Gostin, L. O. and Ó Cathaoir, K. E. (2018). Lurching from complacency to panic in the fights against dangerous microbes: a blueprint for a common secure future. Emory Law Journal, 67(3), 337-396. Retrieved from http://law.emory.edu/elj/_documents/volumes/67/3/gostin-cathaoir.pdf

Campos, P. A., \& Reich, M. R. (2019). Political analysis for health policy implementation. Health Systems Reform, 5(3) 224-235. https://doi.org/10.1080/23288604.2019.1625251

Chantornvong, S., \& McCargo, D. (2001) Political economy of tobacco control in Thailand. Tobacco Control, 10, 48-54. https:// doi.org/10.1136/tc.10.1.48

Colenbrander, S., Birungi, C., \& Mbonye, A. K. (2015). Consensus and contention in the priority setting process: Examining the health sector in Uganda. Health Policy and Planning, 30(5), 555-565. https://doi.org/10.1093/heapol/czu030

Dieleman, J. L., Haakenstad, A., Micah, A., Moses, M., Abbafati, C., Acharya, P., . . Murray, C. J. L. (2018). Spending on health and HIV/AIDS: Domestic health spending and development assistance in 188 countries, 1995-2015. Lancet, 391(10132), 1799-1829. https://doi.org/10.1016/S01406736(18)30698-6 
Slutkin, G., Okware, S., Naamara, W., Sutherland, D., Flanagan, D., Carael, M., ... Tarantola, D. (2006). How Uganda reversed its HIV epidemic. AIDS and Behavior, 10(4), 351-360. https://doi. org/10.1007/s10461-006-9118-2

Gaspar, V., Gupta, S., \& Mulas-Granados, C. (2017). Fiscal politics. Washington, D.C., U.S: International Monetary Fund.

Gilson, L. (ed). (2012). Health policy and systems research: a methodology reader. Geneva: World Health Organization.

Gilson, L., Orgill, M., \& Shroff, Z. C. (Eds.). (2018). A health policy analysis reader: the politics of policy change in low- and middle- income countries. Geneva: World Health Organization.

Gómez, E. J. (2017). Geopolitics in Health: Confronting Obesity, AIDS, and Tuberculosis in the Emerging BRICS Economies. Baltimore, Maryland, U.S: Johns Hopkins University Press.

Government of Uganda. (2017). The Presidential Fast-track Initiative on Ending HIV\&AIDS in Uganda by 2030. Kampala: Uganda AIDS Commission.

Green, E. C., \& Witte, K. (2006). Can fear arousal in public health campaigns contribute to the decline of HIV prevalence? Journal of Health Communication, 11(3), 245-259. https://doi. org/10.1080/10810730600613807

Grépin, K. A. (2012). Efficiency considerations of donor fatigue, universal access to ARTs and health systems. Sexually Transmitted Infections, 88, 75-78.

Haacker, M. (2016). The Economics of the Global Response to HIV/ AIDS. Oxford, U.K: Oxford University Press.

Howlett, M., \& Hogan, J. (2015). Policy Paradigms in Theory and Practice: Discourses, Ideas and Anomalies in Public Policy Dynamics. UK: Palgrave Macmillan.

Howlett, M., McConnell, A., \& Perl, A. (2016). Moving policy theory forward: Connecting multiple stream and advocacy coalition frameworks to policy cycle models of analysis. Australian Journal of Public Administration, 76(1), 65-79. https://doi. org/10.1111/1467-8500.12191

IHME [Institute for Health Metrics and Evaluation]. (2010). Financing global health 2012: the end of the Golden Age? Seattle WA: International Health Metrics and Evaluation, University of Washington. http://www.healthdata.org/policy-report/ financing-global-health-2012-end-golden-age.

IHME [Institute for Health Metrics and Evaluation]. (2019). Development Assistance for Health Database 1990-2017. Seattle, USA: Institute for Health Metrics and Evaluation 
John, P. (1998). Analysing Public Policy. London: Cassell.

Johnston, D. (2013). Economics and HIV: the sickness of economics. London, U.K: Routledge International Studies in Health Economics. https://doi.org/10.4324/9780203768709

Johnston, D., Deane, K., \& Rizzo, M. (Eds.). (2018). The political economy of HIV in Africa. Abingdon, U.K.: Routledge. https://doi. org/10.4324/9781315182629

Kakaire, T., Schlech, W., Coutinho, A., Brough, R., \& Parkes-Ratanshi, R. (2016). The future of financing for HIV services in Uganda and the wider sub-Saharan Africa region: Should we ask patients to contribute to the cost of their care? BMC Public Health, 16(1), 896. https://doi.org/10.1186/s12889-016-3573-0

Kapiriri, L., \& Norheim, O. (2004). Criteria for priority-setting in health care in Uganda: Exploration of stakeholders' values. Bulletin of the World Health Organization, 82, 172-179.

Kingdon, J. W. (1984). Agendas, alternatives and public policies. Boston, MA: Little, Brown.

Kirunga Tashobya, C., Ssengooba, F., \& Oliveira Cruz, V. (Eds). (2006). Health Systems Reforms in Uganda: processes and outputs. Health Systems Development Programme, London School of Hygiene \& Tropical Medicine, UK.

KPMG. (2010). Report for AIDS Development Partners on forensic audit of activities of UAC under the approved integrated workplan for 2008-2009. Nairobi: KPMG.

KPMG. (2013). Civil Society Fund and Partnership Fund Expenditure verification for the period 1 May 2010 to 31 December 2012. Nairobi: KPMG.

Kumar, A. \& Bhawalkar, M. (2016). HIV/AIDS Trust Funds: What do we know? Accessed at https://www.who.int/health_financing/topics/ public-financial-management/D2-S4-Bhawalkaratf.pdf?ua=1

Kutzin, J. (2012). Anything goes on the path to universal coverage? Bulletin of the World Health Organization, 90(11), 867-868. https:// doi.org/10.2471/BLT.12.113654

Lule, E., \& Haacker, M. (2011). The Fiscal Dimension of HIV/AIDS in Botswana, South Africa, Swaziland, and Uganda. Washington, DC: World Bank. https://doi.org/10.1596/978-0-8213-8807-5

Mijumbi, B. P. (2001). Uganda's external debt and the HIPC Initiative. Canadian Journal of Development Studies, 22(2), 495-525, https:// doi.org/10.1080/02255189.2001.9668823 
Ministry of Health. (2017). HIV and AIDS Prevention and Control (HIV and AIDS Trust Fund) Regulations. Kampala: Ministry of Health.

Moszynski, P. (2010). Donor fatigue is slashing access to AIDS care in Africa, warns charity. BMJ (Clinical Research Ed.), 340(may27 2), c2844. https://doi.org/10.1136/bmj.c2844

Odaga, J., \& Lochoro, P. (2006). Budget ceilings and health in Uganda. Kampala, Uganda: Caritas Uganda.

Okware, S., Opio, A., Musinguzi, J., \& Waibale, P. (2000). Fighting HIV/AIDS: is success possible? Bulletin of the World Health Organization, 79(12), 1113-1120. https://www.who.int/bulletin/ archives/79(12)1113.pdf

Okwero, P., Tandon, A., Sparkes, S., McLaughlin, J., Hoogeveen, J. G. (2010). Fiscal space for health in Uganda. World Bank Working Paper No 186. https://doi.org/10.1596/978-0-8213-8290-5

Over, M. (2008). Prevention Failure: The Ballooning Entitlement Burden of U.S. Global AIDS Treatment Spending and What to Do About It, Working Paper 144. Washington, DC: Center for Global Development.

Oxford Policy Management. (2012). Assessment of the Potential of Innovative Financing Mechanisms for HIV, Health, and Development: A Focus on Africa. Oxford, U.K: OPM.

Parkhurst, J. (2017). The politics of evidence: From evidence-based policy to the good governance of evidence. London: Routledge.

Poku, N. K., \& Whiteside, A. (Eds.). (2006). The political economy of AIDS in Africa. Abingdon, U.K.: Routledge.

Potter, B. H, \& Diamond, J. (1999) Guidelines for Public Expenditure Management. Washington, DC: International Monetary Fund

Republic of Uganda. (2014). The HIV and AIDS Prevention and Control Act, 2014. Kampala, Uganda: $\begin{array}{llll}\text { Republic of } & \text { Uganda. }\end{array}$ https://ulii.org/system/files/legislation/act/2014/1/HIV\%20and\%20 AIDS\%20prevention\%20and\%20control\%20act\%202014.pdf

Rivers, B. \& Garmaise, D. (2011). Why the Global Fund cancelled Round 11. GFO Newsletter 170. Aidspan. http://www.aidspan.org/gfo_article/why-global-fund-cancelled-round-11

Sabatier, P., \& Weible, C. (2007). The Advocacy Coalition Framework: Innovations and clarifications. Theories of the Policy Process. P. Sabatier. Cambridge, MA: Westview Press. 
Sabatier, P. (Ed.). (2007). Theories of the Policy Process. Cambridge, MA: Westview Press.

Sadan, E. (1997). Theories of Power. Empowerment and Community Planning. E. Sadan. Tel Aviv: Hakibbutz Hamevchad Publishers.

Schlager, E. (2007). A comparison of Frameworks, Theories, and Models of Policy Process. Theories of the Policy Process. P. Sabatier. Cambridge, MA: Westview Press.

Schmeer, K. (1999). Guidelines for Conducting a Stakeholder Analysis. Bethesda, MD: Partnerships for Health Reform, Abt Associates Inc.

Shiffman, J. (2008). Has donor prioritization of HIV/AIDS displaced aid for other health issues? Health Policy and Planning, 23(2), 95-100. https://doi.org/10.1093/heapol/czm045

True, J. L., Jones, B. D., \& Baumgartner, F. R. (2007). Punctuated- equilibrium Theory: explaining stability and change in public policymaking. In P. Sabatier (Ed), Theories of the Policy Process, 2nd edition. Cambridge, MA: Westview Press.

Tumushabe, J. (2006). The politics of HIV/AIDS in Uganda. Geneva: UNRISD.

UAC [Uganda AIDS Commission]. (2017). Status report on the HIV Prevention and Control AIDS Trust Fund (ATF) regulations. Kampala, Uganda: UAC.

UNAIDS. (2018). AIDSInfo. http://aidsinfo.unaids.org

Walt, G., \& Gilson, L. (1994). Reforming the health sector in developing countries: The central role of policy analysis. Health Policy and Planning, 9(4), 353-370. https://doi.org/10.1093/heapol/9.4.353

Walt, G., \& Gilson, L. (1994). Reforming the health sector in developing countries: The central role of policy analysis. Health Policy and Planning, 9(4), 353-370. https://doi.org/10.1093/heapol/9.4.353

Whiteside, A. (2016). HIV and AIDS: a very short introduction. Oxford: Oxford University Press.

Whiteside, A. (2018). The global politics of HIV and AIDS. In C. McInnes, K. Lee, \& J. Youde (Eds.), The Oxford Handbook of Global Health Politics. Oxford: Oxford University Press.

Whiteside, A. (2019). HIV and AIDS in Africa: Global Politics and Domestic Consequences. In Oxford Research Encyclopedia, Politics. Oxford: Oxford University Press.

Wilson, D. \& Görgens, M. (2016, August) The end of the end of AIDS [blog post]. World Bank Blogs. https://blogs.worldbank.org/health/ end-end-aids 
Wilson, D. \& Whiteside, A. (2016). AIDS at 35: A midlife crisis. African Journal of AIDS Research, 15(4), iiivi. https://doi.org/10.2989/160 85906.2016.1254374

WHO. (2010). Health Systems Financing the Path to Universal Coverage - World Health Report, 2010. Geneva: WHO. https:// www.who.int/whr/2010/en/

Zahariadis, N. (2007). The Multiple Streams Framework: Structure, Limitations, Prospects. Theories of the Policy Process. P. Sabatier. Cambridge, MA: Westview Press.

Appendix I: Chronological developments of HIV financing policy in Uganda 


\begin{tabular}{|c|c|c|}
\hline Period & Key events & Source \\
\hline $1982-1986$ & Very minimal domestic public financing for HIV sensitization & $\begin{array}{l}\text { Slutkin et al., 2006; Okware et al., } \\
2000\end{array}$ \\
\hline 1986 & $\begin{array}{l}\text { President Museveni takes over power and thereafter sends } 60 \text { soldiers for further military } \\
\text { training to Cuba. Upon Cuba testing and diagnosing a number of them with HIV on arrival, } \\
\text { President Fidel Castro relays the potential threat to the army to his Ugandan counterpart. } \\
\text { Consequently, the potential threat that AIDS posed to the army, which was Museveni's } \\
\text { primary power base (as he lacked a political base to govern Uganda then) led to pragmatic } \\
\text { actions such as the set-up of the AIDS and STI Control Program in October 1986, } \\
\text { government's open policy towards HIV and government domestic financing of HIV services } \\
\text { (including external resources mobilisation for the HIV response). }\end{array}$ & Tumushabe (2006) \\
\hline $1986-1989$ & Reinvigorated domestic financing for Abstinence and Behavior Change (AB) programs & Green and Witte (2006) \\
\hline 1988 & Government of Uganda appeals for international support to control the epidemic & Kaleeba et al., 2001 \\
\hline $\begin{array}{l}1989 / 90- \\
1995\end{array}$ & Global Programme on AIDS (GPA) funds $A B$ and Condoms use (ABC) & Okware et al. (2000) \\
\hline 1996 & $\begin{array}{l}\text { Ministry of Health commissioned the first feasibility on health insurance and some limited } \\
\text { community-based health insurance schemes were piloted }\end{array}$ & Basaza et al. (2013) \\
\hline $1995-2000$ & $\begin{array}{l}\text { USAID sexually transmitted infector (STI) project and World Bank multi-country HIV/AIDS } \\
\text { program (MAP) implemented }\end{array}$ & Greene (2011) \\
\hline $1989-2000$ & $\begin{array}{l}\text { Generous debt relief from the international community (i.e. the Paris Club, international } \\
\text { development association (IDA), multilateral debt fund (Uganda) and, heavily indebted poor } \\
\text { countries (HIPC) Initiave (including Enhanced HIPC). }\end{array}$ & Mijumbi (2006) \\
\hline 2001 & $\begin{array}{l}\text { Government of Uganda (GoU) abolishes user fees in all public units with the exception of } \\
\text { the private wings of public hospitals }\end{array}$ & Kirunga et al (2001) \\
\hline 2001 & $\begin{array}{l}\text { The Director General (DG) of Uganda AIDS Commission (UAC) participates - as a member - } \\
\text { of the aids } 2031 \text { Costs and Financing Working Group }{ }^{i} \text {. }\end{array}$ & \\
\hline 2002 & $\begin{array}{l}\text { At global level, the Global Fund to Fight AIDS, Tuberculosis, and Malaria (GFATM) is } \\
\text { established. At national level, the Partnership Fund (PF) was established as a pooled source } \\
\text { of funds from Uganda's AIDS Development Partners. It has been the major source of } \\
\text { funding for the HIV/AIDS coordination and management efforts of UAC and other national } \\
\text { level stakeholders referred to as Self Coordinating Entities (SCEs). }\end{array}$ & \\
\hline 2003 & U.S. President's Emergency Plan for AIDS Relief (PEPFAR) authorized & \\
\hline 2004 & $\begin{array}{l}\text { Fiscal reforms (such as fiscal consolidation, partly through strict adherence to budget } \\
\text { ceilings) usher in a new economic paradigm and entrench the same in the Poverty } \\
\text { Eradication Action Plan (PEAP), the overall framework that guides all the sectors to plan in } \\
\text { the context of poverty eradication }\end{array}$ & Odaga and Lochoro (2006) \\
\hline
\end{tabular}




\begin{tabular}{|c|c|c|}
\hline 2006 & Reported misappropriation of GFATM monies and fallout with major donors & \\
\hline 2007 & $\begin{array}{l}\text { The Civil Society Fund (CSF) is established in June } 2007 \text { as a partnership involving the UAC, } \\
\text { development partners and civil society }\end{array}$ & \\
\hline $2007-2008$ & Global economic crisis & \\
\hline $2008-2013$ & $\begin{array}{l}\text { The donors freeze the funds in Partnership Fund and appoint Deloitte Uganda Limited as } \\
\text { financial managerii. }\end{array}$ & \\
\hline 2009 & $\begin{array}{l}\text { A forensic audit launched at the UAC amid allegations of mismanagement of funds. KPMG } \\
\text { Kenya conducted the audit that was funded and led by the donor community, which } \\
\text { contributes US\$ } 2-4 \text { million annually to a basket Partnership Fund to provide financing to } \\
\text { UAC for HIV/AIDS coordination activities. The audit uncovers serious malfeasance, which } \\
\text { further damages Uganda's already-shaky reputation as a committed partner in the fight } \\
\text { against HIV/AIDS. }\end{array}$ & KPMG (2010) and KPMG (2013). \\
\hline 2011 & $\begin{array}{l}\text { Globally, in 2011, the GFATM faces a crisis of confidence triggered by some negative media } \\
\text { articles. In November 2011, the Board cancelled Round } 11 .\end{array}$ & Rivers and Garmaise (2011) \\
\hline Circa 2010 & $\begin{array}{l}\text { At a time when the effort against HIV/AIDS is slipping in terms of rising prevalence and } \\
\text { drug shortages, there is growing recognition by the Government of Uganda needs to do } \\
\text { much more to ensure that the substantial inflows of donor money are protected and used } \\
\text { for their intended purposes. }\end{array}$ & $\begin{array}{l}\text { Kakaire et al (2016); Lule and Haacker } \\
\text { (2011); Birungi (2012) and Okwero et } \\
\text { al (2010). }\end{array}$ \\
\hline Circa 2010 & $\begin{array}{l}\text { Owing to fiscal pressures on UAC, Kassami (the Permanent Secretary of MoFPED and } \\
\text { Secretary to the Treasury) authorizes (albeit informally) flexibilities within the public } \\
\text { finance management policies to allow UAC to undertake virement of the development } \\
\text { budget to cover for recurrent expenditures (as a stop gap measure). }\end{array}$ & \\
\hline 2011 & $\begin{array}{l}\text { A policy note entitled "Justification for increased sustainable financing for HIV/AIDS in } \\
\text { Uganda" is elaborated proposing establishment of an AIDS Trust Fund }\end{array}$ & \\
\hline 2014 & $\begin{array}{l}\text { The HIV and AIDS trust fund was established in the (otherwise controversialiii) HIV and AIDS } \\
\text { Prevention and Control Act passed by Parliament in May and assented to by the President } \\
\text { in July } 2014\end{array}$ & Republic of Uganda (2014) \\
\hline $\begin{array}{l}2014- \\
2017^{\text {iv }}\end{array}$ & $\begin{array}{l}\text { Contentions within and between several fields of power }{ }^{v} \text { (including negotiations) regarding } \\
\text { the architecture for the ATF }\end{array}$ & $\begin{array}{l}\text { Various CSOs (2017); UAC (2017) and } \\
\text { Ministry of Health (2017) }\end{array}$ \\
\hline 2014 & $\begin{array}{l}\text { Uganda AIDS Commission developed the HIV and AIDS Investment framework titled "A } \\
\text { case for more strategic and increased investment in HIV/AIDS programmes for Uganda } \\
2015-2025 \text { ". The purpose was to bridge the gap between programme needs and } \\
\text { investments in the response especially from domestic financing. }\end{array}$ & UAC (2014) \\
\hline
\end{tabular}


sustainable HIV financing mechanism

Parliamentary Committee on HIV and AIDS received from Cabinet and reviewed the ATF

guidelines for approval.

Operationalisation of the ATF delayed

$2017-\mathrm{ff}$

2018

As part of rationalisation of government ministries, departments and agencies (MDAs), on

$10^{\text {th }}$ September 2018, cabinet made decision to dissolve UAC and merge its functions under

the Ministry of Health. 
' The Costs and Financing Working Group of the aids2031 project - an initiative named for the year marking a halfcentury after the discovery of HIV - rigorously looked at the tough questions now facing policymakers about the future costs of AIDS.

ii This move, to some extent, led to UAC inaction with coordination functions at national and subnational level suffering. This inaction was largely a subtle resistance to external pressures on UAC (and by extension the Government of Uganda) to repay mismanaged resources (as unearthed by the above-mentioned forensic audit), layoff UAC staff, and create new positions (beyond the GoU approved establishment for UAC), including what was deemed as a personal attack on the person of the Director General who had not been found criminally liable in the audit but rather "charged" with the offence framed as "managerial culpability" (see letter by the Chair of the AIDS Development Partners Group (ADPG) to the Attorney General, and this - in some circles - was viewed as witchhunt of a confidant of the Head of State). Additionally, in November 2012, UAC issued an internal audit report indicating that they had concerns about how the Partnership Fund was being managed. KPMG was requested by the AIDS development partners to conduct a special audit of the Partnership Fund and the CSF. KPMG's findings, presented as expenditure verification for the period 1 May 2010 to 31 December 2012, were that both the UAC and the Financial Management Agent were not strictly adhering to the financial management guidelines.

iii Among other measures, this law criminalizes wilful and intentional transmission of HIV and requires victims of sexual offenses, pregnant women, and partners of pregnant women to undergo mandatory HIV testing "for the purpose of prevention of HIV transmission." (Id. § 14.). Whereas the legislation requires that the results of an HIV test be kept confidential and that they be released only to the person tested, there are a number of exceptions to the confidentiality rule.

iv At the time of undertaking this analysis, the ATF was yet to become fully operational. The criticism stems, in part, from the fact that Uganda's Parliament by and large excluded the input of advocacy groups and experts.

${ }^{\vee}$ The key stakeholders involved are: Ministry of Finance, Planning and Economic Development (MoFPED); Uganda Revenue Authority (URA); Ministry of Health (MoH); Parliament (especially the Committee on HIV/AIDS and other related matters); Uganda AIDS Commission (UAC); Civil Society Organisations (CSOs); and AIDS Development Partners (including the United Nations system). 